Egypt. Acad. J. Biolog. Sci., 3 (1): 13-26(2012)

Email: egyptianacademic@yahoo.com

Received: 20 / 5 /2012
D. Histology \& Histochemistry

ISSN: $2090-0775$

www.eajbs.eg.net

\title{
Ultrastructure of the Midgut of theThird Larval Instar of Chrysomya megacephala (Diptera:Calliphoridae) fed on malathion treated diet
}

\author{
Reda F. A. Bakr ${ }^{1 \& 4}$; Rawheia H. Ramadan²; Sanaa El-Sawy ${ }^{3}$ and \\ Samah M. A. Hussien
}

1-Department of Entomology, Faculty of Science, Ain Shams University, Egypt.

2- Department of Entomology, Faculty of Science, Benha University.

2-Central Lab.of analysis of pesticide residues, Agricultural Research Center, Dokki

3-Biology Department, Faculty of Science ,King Khalid Universith, Abha,KSA

\section{ABSTRACT}

Our study established the histopathlogical effect of different dosages malathion on the third larval instar of Chrysomya megacephala. The concentration of malathion increased gradually during the larval stages reaching the maximum concentration in the third instar larvae.The midgut of third larval instar was studied using transmission electron microscope. The most significant alterations were increasing damage to the larvae midgut including columnar prominent ,fat vacuoles, atrophied microvilli. These results indicate that malathion retard larval development.

Keywords: Malathion, Chrysomya megacephala, mid-gut, Ultrastructure.

\section{INTRODUCTION}

Chrysomya megacephala is commonly found in cadavers in many parts of the world (Gruner et al., 2007; Sukontason et al., 2007; Wang et al., 2008) and is used in forensic entomology cases, for postmortem interval determination (Goff \& Odum, 1987; Goff et al.,1988; Goff, 1992). Entomotoxicology is a relatively new branch of forensic entomology. The potential use of necrophagous insects for detecting drugs and other toxins in decomposing carcasses have been widely demonstrated (Nolte et al., 1992; Goff and Lord, 2001; Campobasso et al., 2001; Introna et al., 2001; Kharbouche et al., 2008). The analysis of larvae found in cadavers can, therefore, contribute to the qualitative identification of drugs present in the corpse (Nolte et al., 1992; Kintz et al., 1990a, b; Introna et al., 1990). In addition, drugs in putrefied tissues may have an influence on the development of the necrophagous Diptera that can affect the estimation of the PMI (Goff et al., 1991, 1992, 1993; Bourel et al., 1999; Carvalho et al., 2001; O'Brien and Turner, 2004). Drug levels in larvae could also be correlated to drug concentrations in tissues eaten by the insects, providing valuable information to elucidate the cause of death. The larval behavior toward several substances is unsure; consequently, their use for qualitative identification and quantitative analysis of drugs or toxins are strongly limited (Sadler et al., 1997a, b; Tracqui et al., 2004). Malathion is an organophosphorous insecticide that is employed for both agricultural and medical purposes. It is used throughout the world in a variety of formulations and is widely available. Although it has relatively low toxicity in humans it is metabolised to the more toxic malaoxon in our bodies and if taken to excess can prove fatal. Owing to its ease of availability, malathion is often used as a means of committing suicide particularly among agricultural communities (Thompson et al., 1998; Pannell et al., 2001). The effect of malathion on the development of Chrysomya megacephala is examined by (El-Samad et al., 2006; Rumiza et al., 2008; Xiaoshan Liu et al., 2009), larvae from control group developed more rapidly than 
larvae feeding on tissue containing malathion. The objective of this paper is to illustrate the histological effects on the third laval instar of Chrysomya megacephala tissus contaning malathion.

\section{MATERIAL AND METHODS}

\section{Rearing of flies:}

The colony Chrysomya megacephala was reared in the research laboratory of the Department of Entomology, Faculty of Science, Ain Shams University, Cairo, Egypt, Similar to Sukontason et al. (2004) and Gabre et al. (2005). These fly colonies were maintained at ambient temperature $\left(25.5 \pm 2.5^{\circ} \mathrm{C}\right)$ and natural light/dark photoperiod in a wooden box in the rearing room. Adults were reared on two kinds of food: 1) a mixture of sugar \& powdered milk and 2) fresh pork liver (used as both a food source and ovipostion site). Water supply was a piece of paper as a long thread in a bottle filled with water. Small pieces of fresh pork liver and water supply were changed every 2 days. Subsequently, the ovipostion sites were observed daily for the presence of eggs; if present, the eggs were transferred into a $(12 \times 15 \times 6 \mathrm{~cm})$ transparent plastic box, and $40 \mathrm{~g}$ of fresh pork liver was provided as larval food. The lid of each box was rectangular, likes a fine mesh suitable for ventilation and prevention of other small insects entering the box to oviposit in it. The lid was sealed tightly with adhesive rubber cord to prevent the larvae from crawling out. Immediately after the third larval instars observed, larvae were transferred into the rearing cage $(40 \times 40 \times 56 \mathrm{~cm})$. At the postfeeding stage, dry autoclaved sawdust was added as a medium for pupation. Ch..megacephala reared on rabbits designated as $\mathrm{R}_{0}$ for control colony, $\mathrm{R}_{1}$ for colony fed on rabbits adminesterd $513 \mathrm{mg} / \mathrm{kg}$ malathion and $\mathrm{R}_{2}$ for larvae growing on rabbits treated with $1026 \mathrm{mg} / \mathrm{kg}$ of malathion.

\section{Histological studies:}

Approximately 10 specimens of the third larval instar of Chrysomya megacephala were collected from the rabbit carcasses for each experiment and then placed in $3 \%$ glutraldehyde, buffered to $\mathrm{pH} 7.3$ at $4{ }^{\circ} \mathrm{C}$. After one hour a cut was made with a sharp razor blade to divide the larvae into many portions. Then larvae were cut into small pieces, about $1 \mathrm{~mm}^{2}$ each .The samples were placed in fresh $5 \%$ cold glutraldehyde and fixation was continued for 24 hours. Samples were then washed in two changes of cold phosphate buffer, $\mathrm{pH} 7.3$, for 1 hour. The specimens were then post-fixed for 1-2 hours in buffered $1 \%$ osmium tetraoxide. They were washed twice

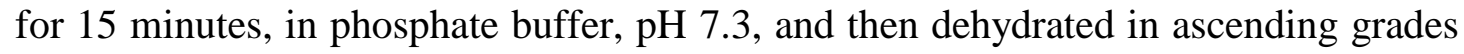
of ethanol to propylene oxide $(30 \%, 40 \%, 50 \%, 60 \%, 70 \%, 80 \%, 90 \%, 95 \%$ and absolute), infiltration with acetone for 30 minutes and embedded in Araldite each (Khattab et al., 2004). Semithin sections of $0.7 \mathrm{~m}$ thickness were cut with glass knives on the 6000 MT RMC ultratome. Stained with $0.25 \%$ toludine blue (Davis, 1971).and examined by light microscopy. Thin sections (600-700 A) were then cut and collected on copper grids. These sections were stained with uranyl acetate and lead citrate and examined photographed in a JEOL 1200 EXIL transmission electron microscope at the Electron Microscope unit, Faculty of Science, Ain Shams University.

\section{RESULTS}

\section{For larvae reared on control colony:}

The alimentary canal consists of foregut, midgut and hindgut. The larval midgut of Chrysomya megacepha is the longest portion of the alimentary canal lying 
convoluted and twisted within the larval body cavity (Worachote et al. 2007).

The epithelial cells of the mid gut include two types of cells, more electron dense and intestinal cells less (Fig. 1\& 2). The nucleus is slightly regular, and has prominent nucleoli, with clumped eu and heterochromatin (Fig. 2). The most abundant organells are mitochondria (elongated\& rounded) and small dense lysosomes that scattered in between mitochondria (Fig. 4). Long attached microvilli (Fig. 4). The cytoplasm lacked granules (fats \& glycogen). The rest of cytoplasm is rarified (not compact) and containing small elements of rough \& smooth endoplasmic reticulum (Fig. 1).

\section{For larvae reared on $R_{1}$ colony:}

Effect of malathiont on the third instar larvae increased with an increase of concentration. Regression analysis showed a correlation between concentration in larvae and administered dosage of malathion $(r=0.9974, p=0.046)$.

The most characteristic changes in this group are: Dense compressed cells with irregular, shrinked nucleus that has fragmented nucleoli and no clumped chromatin (Figs.6 a\&b). Engulfed cytoplasmic granules in prominent mitochondria located at the periphery and absence of lysosomes (Fig. 7). There are a number of fat vacuoles at the periphery in between mitochondria (Fig. 8).

\section{For larvae reared on $\mathbf{R}_{2}$ colony:}

Most cells are lacked so, it is hardly to distinguish prominent nuclei in the most midgut intestinal cells.

The most histological alterations of this group are: No dark or light, all cells are damaged, containing prominent fat vacuoles and coagulated cytoplasmic granules \& organelles (Figs.1a\&b). The cells possessing short, shrinkage or atrophied microvilli (Fig. 4).

Data revealed that different toxic effects of malathion varied according to the the insecticide concentration.

\section{DISCUSSION}

Third larval instar midgut of Ch. megacephala is functionally the most important part of the digestive system, responsible for digestion and absorption of nutrients as in other insect larvae (Dow 1986). The midgut of Ch. megacephala is similar to those of other Diptera. Romoser (1996), reported that the presence of microvilli provide an enormous surface area for absorbing materials from the lumen. The thickness of the basement membrane in Ch. megacephala is due to the good nutrition during the larval stage (Clements, 1992) which facilitates the transport of products between the intestine and the haemolymph (Reinhardt and Hecker, 1973; Houk et al., 1980). The cytoplasm of mid-gut cells of Ch.megacephala possesses numerous vesicles of rough endoplasmic reticulum. Authors interpret this phenomenon as a transition of the cell synthetic apparatus into a more active state (Billingsley et al., 1983; Lehane 1976a; Staubli et al., 1966 and Filimonova, 1989). More mitochondria are located at the periphery of the cell more than basal part which indicated that the transport role by the apical part more functionally than the basal part (Hecker 1977and Houk, 1977). Observation of numerous secretory granules with different shapes and sizes, most of which located at the periphery and some of them project in the gut lumen. According to Chun-Nu et al. (2000), the release of digestive enzymes from midgut cells of oriental fruit fly is merocrine due to high concentration of secretory granules in the apical part of the cell. Also the presence of numerous secretory granules and numerous vesicles of rough endoplasmic reticulum in $\mathrm{Ch}$, 
megacephala near the periphery of the cell may account for the production of peritrophic membrane as reported by Filimonova (2005).

Malathion concentration increased gradually until the third instar larval stage after which it decreased. This phenomenon can be explained by the fact that larval stages with increased malathion concentrations had a period of rapid feeding and thus excluded the postfeeding prepupal stage (Hedouin et al., 1999).

The highest concentration of malathion was found in gastric content (Farago, 1967; Morgade \& Barquet, 1982; Jadhav et al., 1992; Mahat, N.A. et al., 2012). According to insectidal action of malathion, the development of the third larval instar of Ch. megacephala was retarded. (Lamia M. El-Samad et al., 2006, Rumiza Abd. Rashid $^{1}$ et al., 2008, Xiaoshan Liu et al., 2009).

The most characteristic histopathological effects of malathion on the midgut of Ch. megacephala were in concurrence with those findings previously reported, (Hassan F. Dahi ${ }^{1}$ et al., 2011) observed that Spodoptera littoralis was affected by the action of pyridalyl, the epithelial cells were completely ruptured after treatment and separated from the basement membrane. The peritrophic membrane was not closely lying to the epithelial cells and the space in between the epithelium and peritrophic membrane was filled with few cytoplasmic vesicles. (Habes Da. et al., 2006) stated that boric acid toxicity to midgut of Blattella germanica, revealed alterations in the epithelial cells and a significant increase in the epithelium thickness. Assar and ElSobky (2003) observed that the water extract of Eichhornia crassipes on larvae of Culex pipiens, revealed drastic effect on larval midgut as the brush border and most of the epithelial cells completely degenerated and vacuolated.

\section{REFERENCES}

Billingsley, P.F. and Downe, A.E.R., (1983). Ultrastructural Changes in Posterior Midgut Cells Associated with Blood Feeding in Adult Female Phodnius prolixus Stal (Hemiptera: Reduviidae), Can. J. Zool., 61, p. 2574-2586.

Bourel, B., Hedouin V., Martin-Bouyer L., Becart A., Tournel G., Deveaux M. and Gosset D. (1999). Effects of morphine in decomposing bodies on the development of Lucilia sericata (Diptera: Calliphoridae). J. Forensic Sci., 44: 354-358.

Campobasso, C.P., Di Vella G. and Introna F. (2001). Factors affecting decomposition and Diptera colonization. Forensic Sci. Int., 120: 18-27.

Carvalho, L.M., Linhares A.X. and Trigo J.R. (2001). Determination of drug levels and the effect of diazepam on the growth of necrophagous flies of forensic importance in southeastern Brazil. Forensic Sci. Int., 120: 140-144.

Chun-Nu Hung, Tai-Lung Lin and Wen-Yung Lee (2000).Morphology and ultrastructure of the alimentary canal of the oriental fruitfly,Bactrocera dorsalis (Hendel) (Diptera:Tephritidae)(2):The structure of the midgut.Zoological Studies 39(4):387-394

Clements, A. N. (1992). Development, Nutrition and Reproduction In: The Biology of Mosquitoes. London, Chapman \& Hall, p. 509.

Davis, D. (1971). Histopathologic Technic and practical Histochemistry. Mc GrawHill, New York $3^{\text {rd }}$ ed., 112.

Dow (1986). Insect midgut function. Adv. Insect Physiol.19:187-328. Environmental Health 10(2): 321-325.

Farago, A. (1967). Fatal, suicidal malathion poisonings. Archiv fur Toxikologie 23:11-16. 
Filimonova (2005). Morphological study of digestive cycle in bloodsucking biting midges of Genus Culicoides. Journal of Evolutionary Biochemistry and Physiology 41(2):176-185.

Filimonova (2005). Morphological study of digestive cycle in bloodsucking biting midges of Genus Culicoides.Journal of Evolutionary Biochemistry and Physiology, 4(2):176-185.

Filimonova, S.A., (1989). Morphological Analysis of Digestion in the Flea Leptopsylla segnis (Siphonaptera: Leptopsyllidae), Parazitologiya, 23: 480.488.

Gabre, M.R., Adham, K.F. \& Chi, H. (2005). Life table of Chrysomya megacephala (Fabricius) (Diptera: Calliphoridae). Acta Oecologica 27: 179-183.

Goff, M. L., and Odom C. B. (1987). Forensic entomology in the Hawaiian Islands: three case studies. Am. J. Forensic Merl. Pathol. 8: 15-50.

Goff, M. L., Omori, A. I. \& Gunatilake, K. (1988). Estimation of postmortem interval by arthropod succession - Three case studies from the Hawaiian

Goff, M. L., Omori, A. I. and Gunatilake, K. (1988). Estimation of postmortem interval by arthropod succession-Three case studies from the Hawaiian Islands. American Journal of Forensic Medicine and Pathology, 9: 220-225.

Goff, M.L. and Lord W.D. (2001). Entomotoxicology: Insects as Toxicological Indicators and the Impact of Drugs and Toxins on Insect Development. In: Forensic Entomology, The Utility of Arthropods in Legal Investigations, Byrd, J.H. and J.L. Castner (Eds.). New York, USA.

Goff, M.L., Brown W.A. and Omori A.I. (1992). Preliminary observations of the effect of methamphetamine in decomposing tissues on the development of Parasarcophaga ruficornis (Diptera: Sarcophagidae) and implications of this effect on the estimations of postmortem intervals. J. Forensic Sci., 37: 867-872.

Goff, M.L., Brown W.A., Hewadikaram K.A. and Omori A.I. (1991). Effect of heroin in decomposing tissues on the development rate of Boettcherisca peregrina (Diptera, Sarcophagidae) and implications of this effect on estimation of postmortem intervals using arthropod development patterns. J. Forensic Sci., 36: 537-542.

Goff, M.L., Brown W.A., Omori A.I. and La Pointe D.A. (1993). Preliminary observations of the effects of amitriptyline in decomposing tissues on the development of Parasarcophaga ruficornis (Diptera: Sarcophagidae) and implications of this effect to estimation of post mortem interval. J. Forensic Sci., 38: 316-322.

Gruner, S. V., Slone, D. H. and Capinera, J. L. (2007). Forensically important Calliphoridae (Diptera) associated with pig carrion in rural north-central Florida. Journal of Medical Entomology, 44: 509-515.

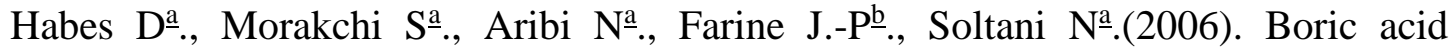
toxicity to the German cockroach, Blattella germanica: Alterations in midgut structure, and acetylcholinesterase and glutathione $S$-transferase activity. Pesticide Biochemistry and Physiology. 84(1): 17-24.

Hassan F. Dahi, Aida, S.Kamel, Nehad, M. El Barkey and Mona F. Abd-El Aziz. (2011). Pyridalyl Effectiveness on Some Biological and Physiological Parameters of Cotton Leafworm Spodoptera littoralis (Boisd.) (Lepidoptera: Noctuidae). Journal of American Science 7(12):855-863.

Hecker, H. (1977) .Structure and function of midgut epithelial cells in culicidae mosquitoes (Insecta, Diptera). Cell Tissue Res 184:321-341.

Hedouin, V., Bourel, B., Martin-Bouyer, L.,Becart, A., Tournel, G., Deveaux, M. \&Gosset, D. (1999). Determination of drug levels in larvae of Luciliasericata 
(Diptera :Calliphoridae) reared on rabbit carcasses containing morphine. Journal of Forensic Sciences 44(2): 351-353.

Houk, E. J.; Chiles, R. E. \& Hardy, J. L. (1980). Unique midgut basal lamina in the mosquito Aedes dorsalis (MEIGEN) (Insecta, diptera). Int.J. Insect. Morphol. Embryol 9:161-4

Houk, E.J. (1977). Midgut Ultrastructure of Culex tarsalis (Diptera: Culicidae) before and after Bloodmeal, Tiss.Cell, 9:103.118.

Introna, F., Dico L.C., Caplan Y.H. and Smialek J.E. (1990). Opiate analysis in cadaveric blowfly larvae as an indicator of narcotic intoxication. J. Forensci Sci., 35: 118-122.

Introna, F.Jr., Campobasso C.P. and Goff M.L.( 2001). Entomotoxicology. Forensic Sci. Int., 120: 42-47..

Jadhav, R.K., Sharma, V.K., Rao, G.J., Saraf, A.K. \& Chandra, H. (1992). Distribution of malathion in body tissues and fluids. Forensic Science International 52: 223-229.

Kharbouche, H., M. Augsburger, D. Cherix, F. Sporkert and C. Giroud et al.(2008). Codeine accumulation and elimination in larvae, pupae and imago of the blowfly Lucilia sericata and effects on its development. Int. J. Legal Med., 122: 205-211.

Khattab, F. ; Khattab, F. I. ; Fares, N. and Zaki, A. (2004). Ultrastructural studies of the pigment epithelium of retinae of some reptiles. The Egyptian Journal of Hospital Medicine, 17:115 - 129.

Kintz, P., Tracqui A. and Mangin P. (1990). Toxicology and fly larvae on a putrefied cadaver. J. Forensic Sci. Soc., 30: 243-246.

Lehane, M. J. \& Billingsley, P. F. (1996). Structure and ultrastructure of the insect midgut. In: Biology of the Insect Midgut. Chapman \& Hall, p. 486.

Mahat, N.A.*, Jayaprakash, P.T. and Zafarina, Z. (2012).Malathion extraction from larvae of Chrysomya megacephala (Fabricius) (Diptera: Calliphoridae) for determining death due to malathion. Tropical Biomedicine 29(1):9-17

Morgade, C. \& Barquet, A. (1982). Body distribution of malathion and its metabolites in fatal poisoning by ingestion. Journal of Toxicology and Environmental Health, 10(2):321-325.

Nolte, K.B., Pinder R.D. and Lord W.D. (1992). Insect larvae used to detect cocaine poisoning in a decomposed body. J. Forensci Sci., 37: 1179-1185.

O'Brien, C. and Turner B. (2004). Impact of paracetamol on Calliphora vicina larval development. Int. J. Legal Med., 118: 188-189.

Pannell, M., Gilbert, J.D., Gardiner, J. \& Byard, R.W. (2001). Death due to malathion poisoning. Journal of Clinical Forensic Medicine 8: 156-159.

Reinhardt, C. \& Hecker, H. (1973). Structure and function of the basal lamina and of the cell junctions in the midgut epithelium (stomach) of female Aedes aegypti L. (insecta: diptera). Acta Trop., 30 (3):213-35

Rumiza Abd. Rashid ${ }^{1}$, Khairul Osman ${ }^{1}$, Mohd Iswadi Ismail ${ }^{2}$, Raja Muhammad Zuha ${ }^{1}$ and Rogayah Abu Hassan ${ }^{1}$. (2008). Determination of malathion levels and the effect of malathion on the growth of Chrysomya megacephala (Fibricius) in malathion-exposed rat carcass. Tropical Biomedicine 25(3): 184-190

Sadler, D.W.; Seneviratne C. and Pounder D.J. (1997). Effects of 3,4methelenedioxymethamphetamine in decomposing tissues on the development of Parasarcophaga ruficornis (Diptera: Sarcophagidae) and detection of the drug in postmortem blood, liver tissue, larvae and pupae. J. Forensic Sci., 42: 1212-1213. 
Stäubli, W., Freyvogel, T.A., and Suter, J. (1966). Structural Modification of the Endoplasmic Reticulum of Midgut Epithelial Cells of Mosquitoes in Relation to Blood Intake. J. Microscopie, vol. 5, pp. 189.

Sukontason K, Narongchai P, Kanchai C, Vichairat K, Sribanditmongkol P, Bhoopat T, Kurahashi H, Chockjamsai M, Piangjai S, Bunchu N, Vongvivach S, Samai W, Chaiwong T, Methanitikorn R, Ngern-Klun R, Sripakdee D, Boonsriwong W, Siriwattanarungsee S, Srimuangwong C, Hanterdsith B, Chaiwan K, Srisuwan C, Upakut S, Moopayak K, Vogtsberger RC, Olson JK, Sukontason KL.(2007) Forensic entomology cases in Thailand: a review of cases from 2000 to 2006. Parasitology Res.101(5):1417-23.

Sukontason $\mathrm{K}^{1}$., Sukontason K.L., Radchadawan Ngern-Klun, Duanghatai Sripakdee, And Somsak piangjai. (2004). Differentiation of the Third Instar of Forensically Important Fly Species in Thailand. Ann. Entomol. Soc. Am. 97(6): 1069-1075 .

Thompson, T.S., Treble, R.G., Magliocco, A.,Roettger, J.R. \& Eichhorst, J.C. (1998). Case study: fatal poisoning by malathion. Forensic Science International 95: 89-98.

Tracqui, A., Keyser-Tracqui C., Kintz P., Ludes B. (2004). Entomotoxicology for the forensic toxicologist: Much ado about nothing. Int. J. Legal Med., 118: 194-196.

Wang J, Li Z, Chen Y, Chen Q, Yin X. (2008). The succession and development of insects on pig carcasses and their significances in estimating PMI in south China. Forensic Sci Int. 179(1):11-18.

Worachote Boonsriwong \& Kom Sukontason \& Jimmy K. Olson \& Roy C. Vogtsberger \& Udom Chaithong \& Budsabong Kuntalue \& Radchadawan Ngern-klun \& Surasak Upakut \& Kabkaew L. Sukontason (2007). Fine structure of the alimentary canal of the larval blow fly Chrysomya megacephala (Diptera: Calliphoridae). Parasitol Res 100:561-574.

Xiaoshan Liu, Yanwei Shi, Haiyang Wang, Runjie Zhang. (2009). Determination of malathion levels and its effect on the development of Chrysomya megacephala (Fabricius) in South China. Forensic Science International 192(1-3): 14-18. 


\section{Control group}

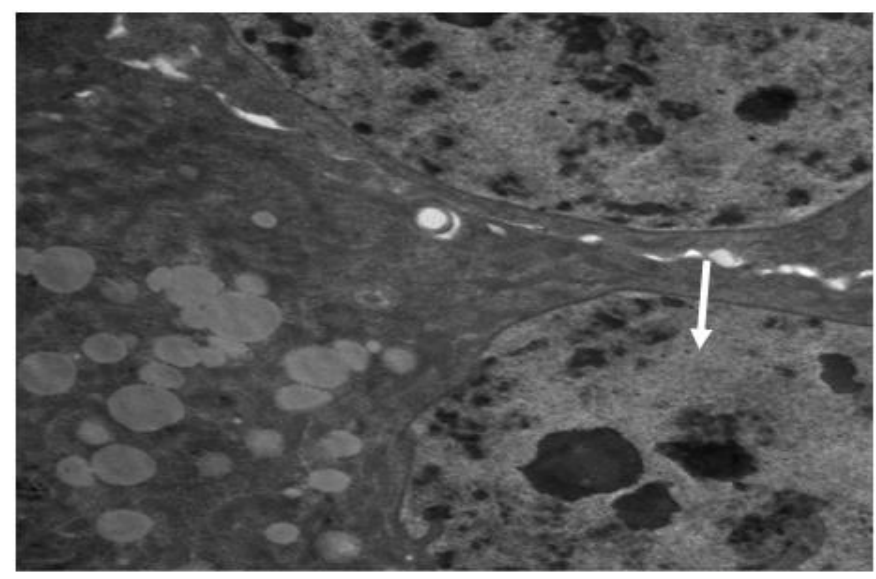

Fig. 1: Electron micrograph of a dark columnar cell (dense compressed cells) in middle mid-gut showing nucleus (arrow). Magnification X 2,000.

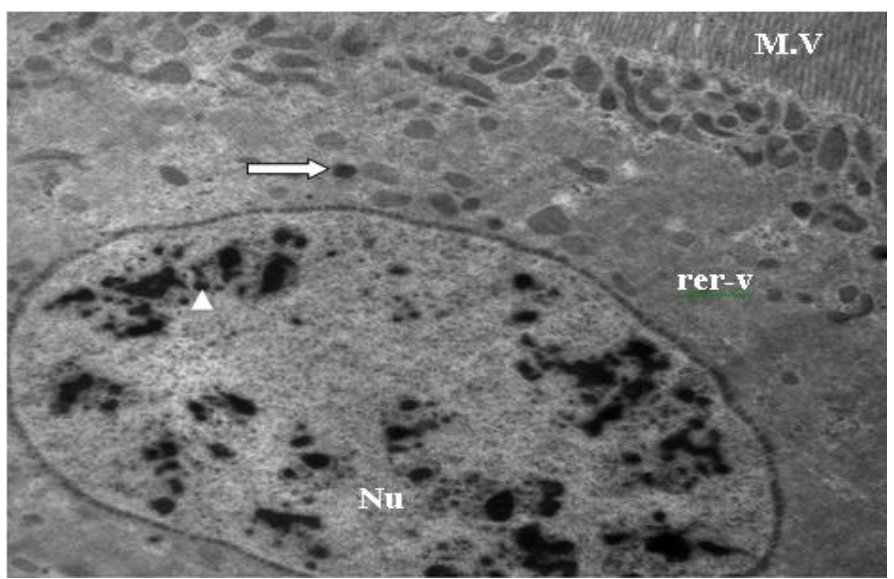

Fig. 2: Electron micrograph of a light columnar cell in middle mid-gut (less electron dense cytoplasm) showing nucleus $(\mathrm{Nu})$ surrounded by numerous vesicles of rough endoplasmic reticulum (rerv) and chromatin patches of varying densities (head arrow) lysosomes (arrow). Magnification $\mathrm{X} 1,500$.

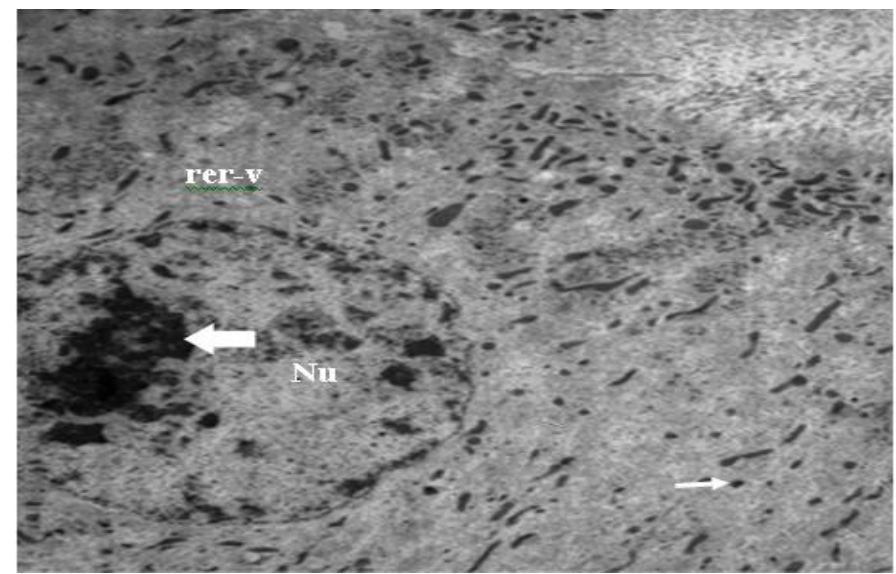

Fig. 3: Electron micrograph of a columnar cell in middle mid-gut showing nucleus $(\mathrm{Nu})$ surrounded by numerous vesicles of rough endoplasmic reticulum (rer-v), lysosmes (arrow) and clumped (eu \& hetero) chromatin (big arrow). Magnification X 1,000. 


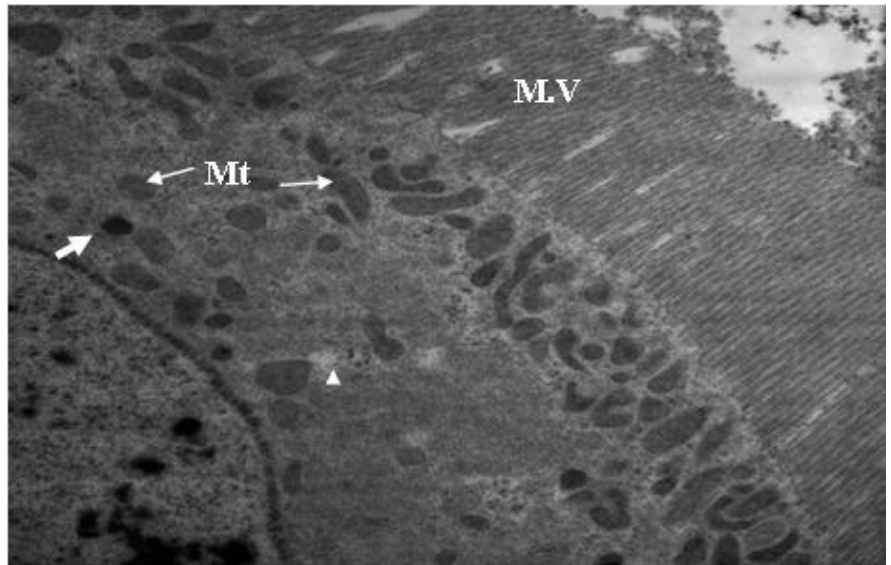

Fig. 4a: Electron micrograph of a dark columnar cell in middle mid-gut showing microvilli (Mv), small dense secretory granules (arrow), small vesicles of rough endoplasmic reticulum (head arrows) and elongated \& oval mitochondria (M.t). Magnification X 2,000.

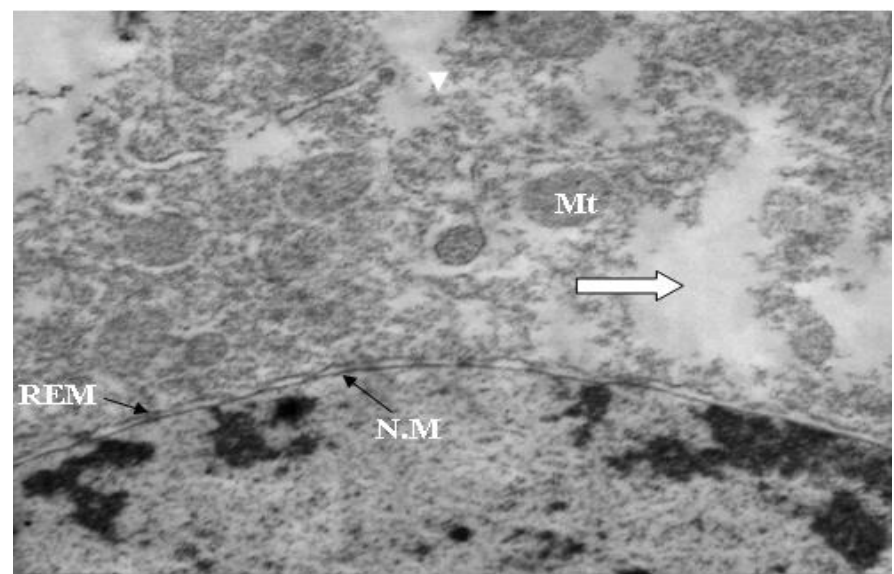

Fig. 4b: Electron micrograph of a columnar cell in middle mid-gut showing rarified mitochondria (M.t), rarified areas of cytoplasm (big white arrow), ribosomes (head arrow), rough endoplasmic membrane (REM) and Nuclear membrane (N.M). Magnification X 5,000.

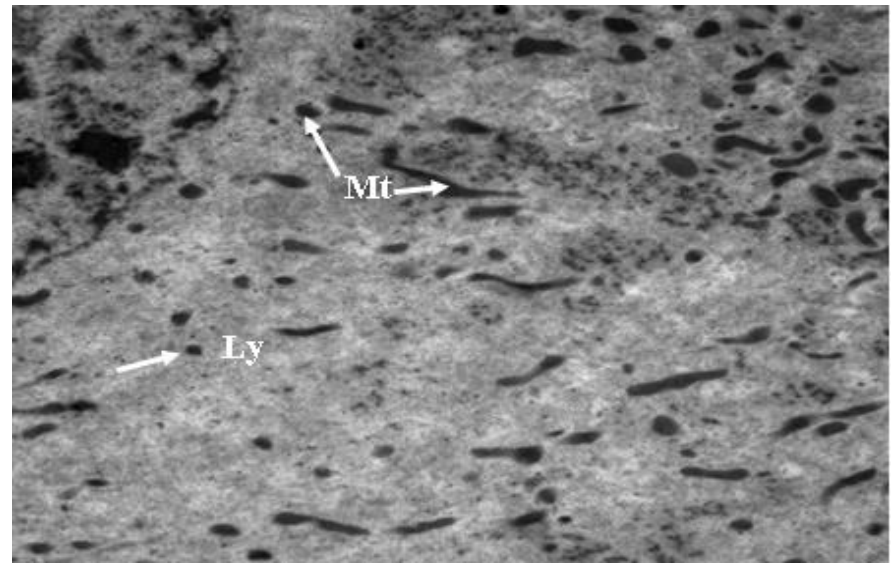

Fig. 5: Electron micrograph of a columnar cell in middle mid-gut showing rarified mitochondria (M.t) and homogenously scattered lysosomes (Ly) between mitochondria. Magnification X 2,000. 


\section{First dose group}

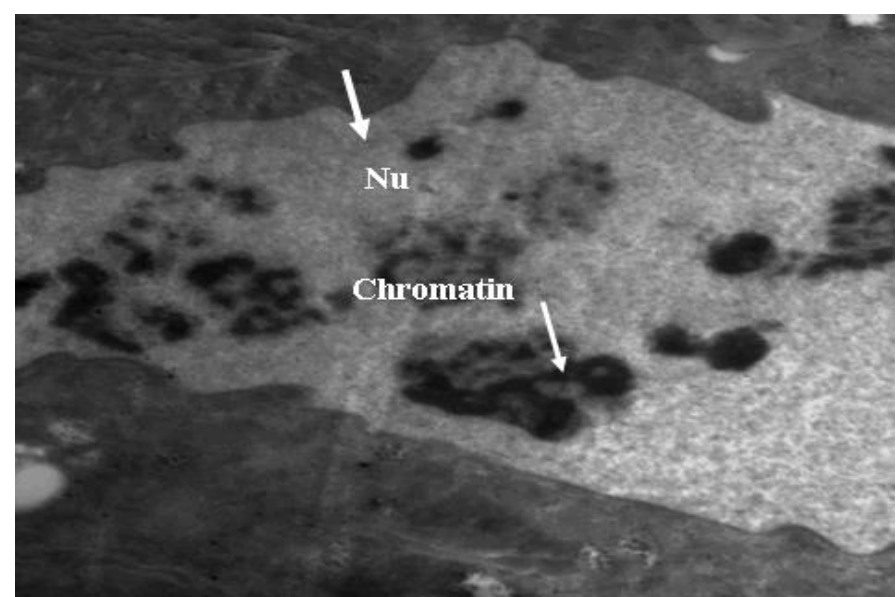

Fig. 6 a: Electron micrograph of a dark columnar cell in middle mid-gut showing irregular nucleus and lacked clumped of chromatin. Magnification X 2,000.

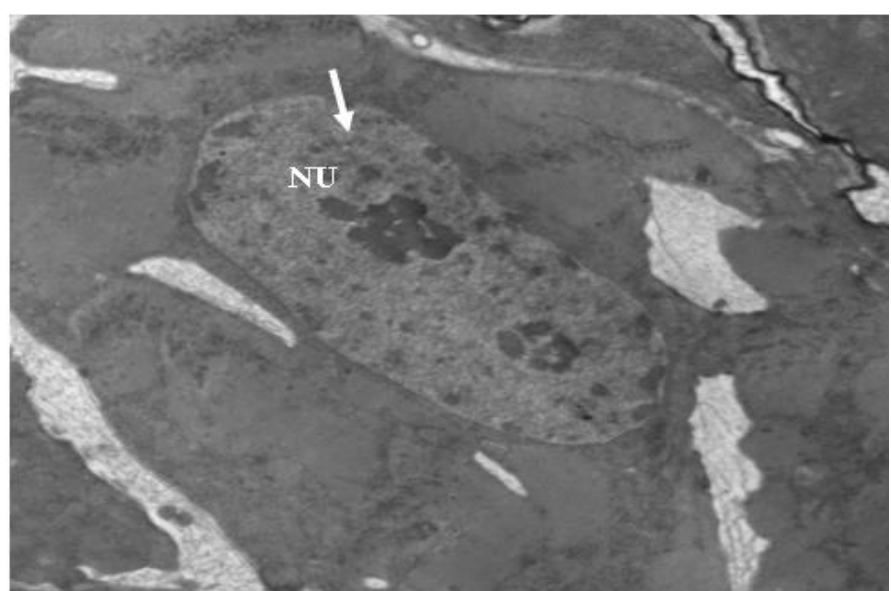

Fig. 6 b: Electron micrograph of a dark columnar cell in middle mid-gut showing irregular nucleus. Magnification X 2,000.

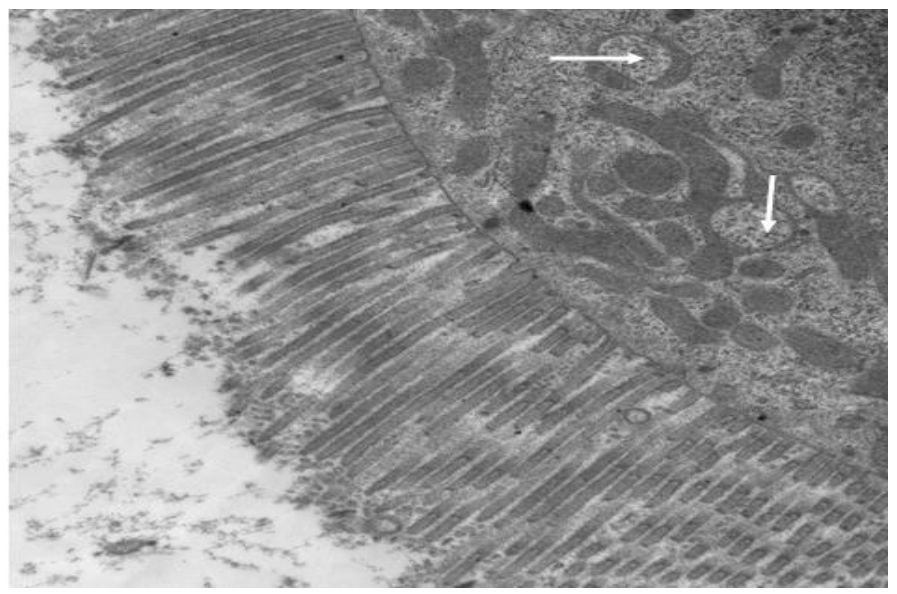

Fig. 7: Electron micrograph of a columnar cell in middle mid-gut showing significant engulfed granules in curved mitochondria. . Magnification X 4,000. 


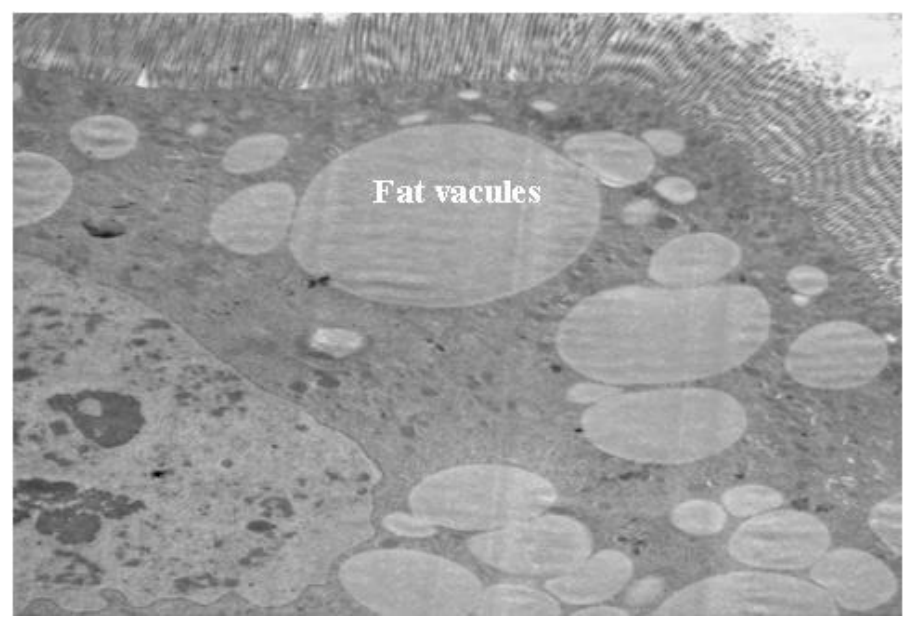

Fig. 8: Electron micrograph of a columnar cell in middle mid-gut showing accumulation of fat vacules at the periphery in between mitochondria and absence of lysosomes. Magnification X 1,200.

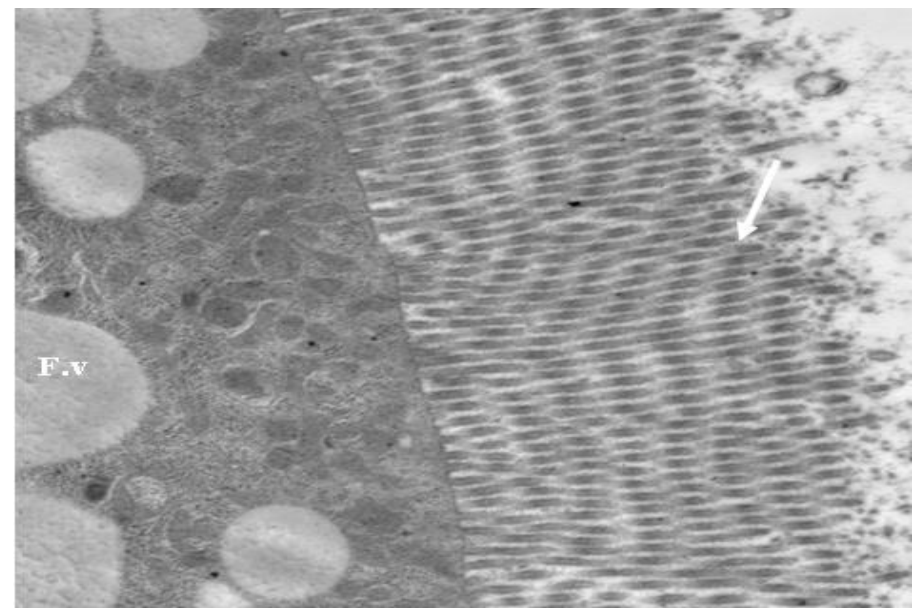

Fig. 9: Electron micrograph of a columnar cell in middle mid-gut showing no change in M.V (arrow) \& fat vacuoles (F.v) in between mitochondria. Magnification X 4,000. 


\section{Second dose group}

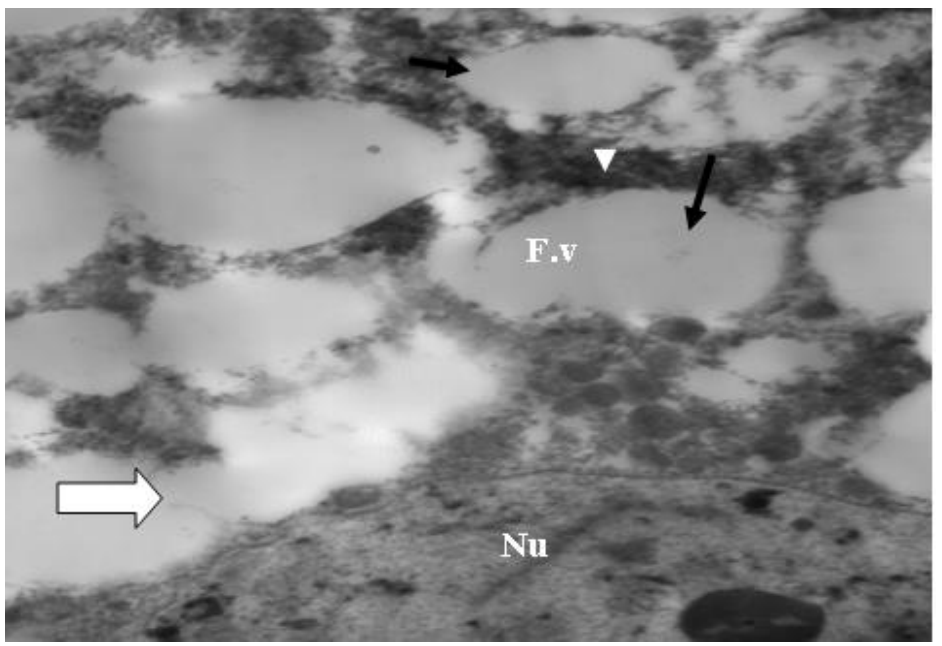

Fig. 10.a: Electron micrograph of a columnar cell in middle mid-gut showing nucleus (Nu) abundant of fat vacuoles (black arrows) and rarified areas of cytoplasm (white arrows) \& coagulated cytoplasmic granules \& organells (head arrow). Magnification X 2,000.

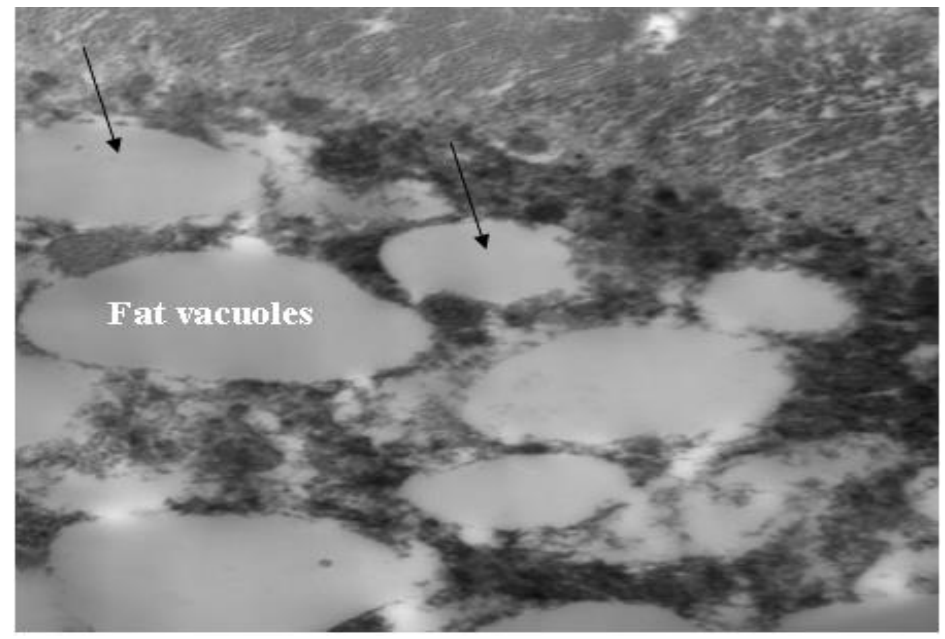

Fig. 10-b: Electron micrograph of a columnar cell in middle mid-gut showing abundant of fat vacuoles (black arrows). Magnification X 2,000. 


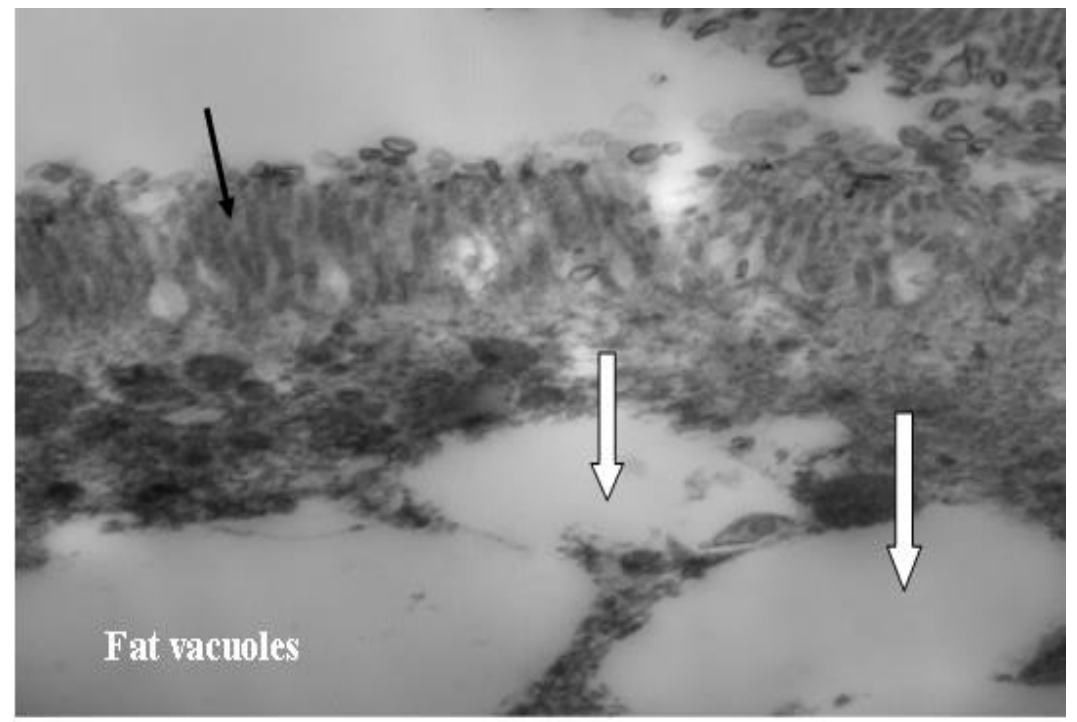

Fig. 11: Electron micrograph of a columnar cell in middle mid-gut showing abundant of fat vacuoles (white arrows) microvilli shrinkage (black arrow). Magnification X 4,000.

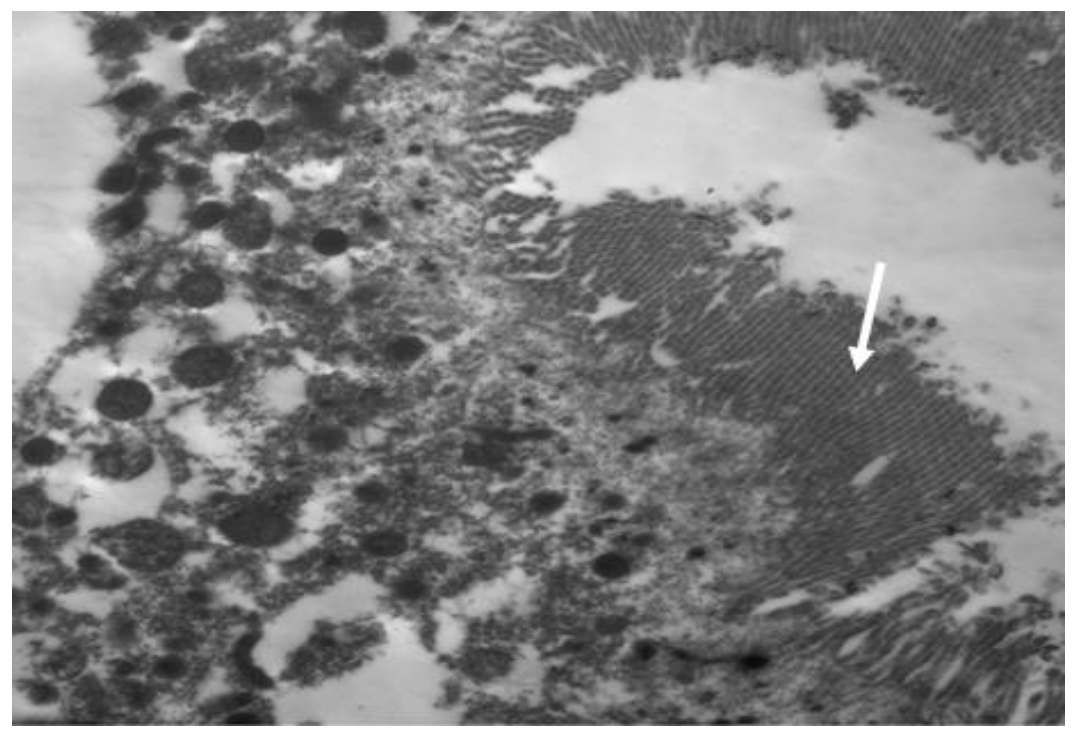

Fig. 12: Electron micrograph of a columnar cell in middle mid-gut showing coagulated and shrinkage microvilli. Magnification X 2,000. 


\section{ARABIC SUMMARY}

التركيب فائق الدقة للمعى المتوسط للطور اليرقى الثالث لحشرة كريسوميا ميجاسفالا

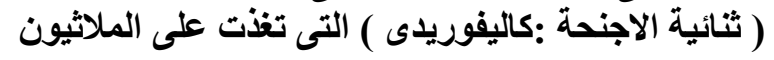

رضا فضيل على بكر 4\&1، روحية حسن رمضان2 ، سناء محمد عبدالقادر الصاوى33 وسماح محمد احمد .

$$
\begin{aligned}
& \text { 1- قسم عام الحشرات ـ كلية العلوم - جامعة عين شمس علمس }
\end{aligned}
$$

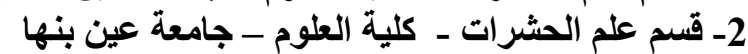

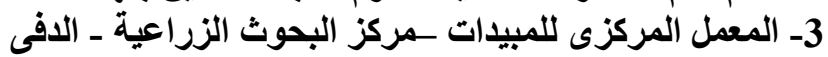

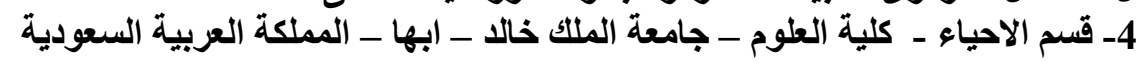

اوضحت هذه الدراسة النأثير ات المرضية للانسجة الناتجة عن جر عات مختلفة من المالاثيون على الطور

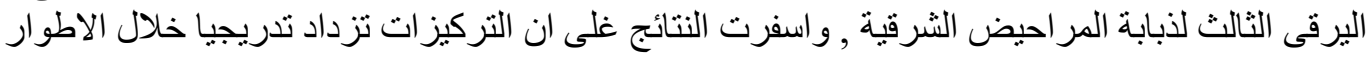

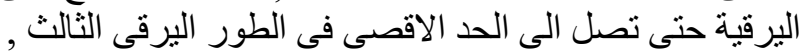

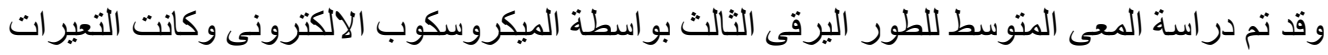

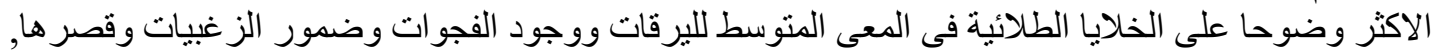
و اشارت النتائج على ان المالاثيون سبب تأخر نمو اليرقات النات 